\title{
Connecting with home, keeping in touch: physical and virtual mobility across stretched families in sub-Saharan Africa
}

\author{
Gina Porter, Kate Hampshire, Albert Abane, Alister Munthali, \\ Elsbeth Robson, Augustine Tanle, Samuel Owusu, \\ Ariane de Lannoy and Andisiwe Bango
}

\begin{abstract}
Introduction
Across sub-Saharan Africa, myriads of so-called 'stretched families' ${ }^{1}$ strive to maintain contact. There is a long history of migration in low-income communities, whereby (usually young, often male ${ }^{2}$ ) members leave home to seek their fortune in what are perceived to be more favourable locations - perhaps a highpotential agricultural area, a booming mining site, secondary town or major city, whether in the home country or abroad (see, for example, Swindell 1980; Englund 2002; Cliggett 2005; Potts 2010; van der Geest 2010). For many such
\end{abstract}

Gina Porter is a professor in the Department of Anthropology, Durham University. Email: r.e.porter@durham.ac.uk

Kate Hampshire is a professor in the Department of Anthropology, Durham University. Email: k.r.hampshire@durham.ac.uk

Albert Abane is a professor in the Department of Geography and Regional Planning, University of Cape Coast, Ghana. Email: abanealbert@gmail.com

Alister Munthali is an associate professor of research and former director of the Centre for Social Research, Chancellor College, University of Malawi. Email: amunthali@cc.ac.mw

Elsbeth Robson is a senior lecturer in the Department of Geography, University of Hull. Email: e.robson@hull.ac.uk

Augustine Tanle is an associate professor in the Department of Population and Health, University of Cape Coast, Ghana. Email: atanle@ucc.edu.gh

Samuel Owusu is an assistant research fellow in the Directorate of Research, Innovation and Consultancy at the University of Cape Coast, Ghana. Email: kowuuus@gmail.com

Ariane de Lannoy is a senior researcher at the Southern Africa Labour and Development Research Unit, Poverty and Inequality Initiative, University of Cape Town. Email: ariane. delannoy@uct.ac.za

Andisiwe Bango is a lecturer at Walter Sisulu University, South Africa. Email: abango@wsu.ac.za

${ }^{1}$ We use the term 'stretched family' as shorthand to describe situations in which migrants maintain close relations - emotional and material - with members of their family left behind, as evocatively described in a Southern African context by Murray (1981). The specific term 'stretched household' is used in South African contexts by Spiegel et al. (1996) and also by Skuse and Cousins (2005). The concept also has wider resonance across Africa: for instance, see <http:/l rurbanafrica.ku.dk/publications/rurbanafrica-project-reports/2._D2-2_Main_report_Mobility_ and_Livelihood_Transformation_of_Households_in_Rural_Cameroon-Ghana_and_Tanzania.pdf $>$, accessed 22 March 2017. However, given debates concerning 'household' as an analytical concept (see Guyer 1981), we have preferred to refer specifically to family. Bryceson and Vuorela (2002: 3), in similar vein, refer to transnational families whose members live some or most of the time separated from each other, yet hold together something that can be seen as a feeling of collective welfare and unity, namely 'familyhood'. De Bruijn et al. (2013: 11) use the term 'strings of people', but this encompasses migrant networks that extend more widely than family.

${ }^{2}$ See Hall et al. (2015), for instance, for South Africa.

(C) International African Institute 2018. This is an Open Access article, distributed under the terms of the Creative Commons Attribution licence (http://creativecommons.org/licenses/by/4.0/), which permits unrestricted re-use, distribution, and reproduction in any medium, provided the original work is prop- 
families, migration is part of the social fabric of life, despite sometimes ugly past experiences, especially in South Africa (Stichter 1985). It is a 'productive bricolage' exploiting opportunities wherever and whenever they emerge (Batterbury 2001). However, for both those who leave home and those who remain, maintaining contact with distantly located close kin is commonly of crucial importance for the maintenance of emotional (and often material) well-being. In part, this can be attributed to the nature of migration, which so often still takes a circular character, albeit with variations influenced by a wide array of structural conditions (Potts 2010: 254). This article explores how connecting with home is being reshaped by the availability of mobile phones, with particular reference to emotional repercussions at either end of the stretched family. While there is growing interest in ICT usage in Africa, including ICT-mediated connections with migrants, many studies are limited in their spatial scope within Africa and tend to draw principally on either ethnographic or quantitative methods, depending on disciplinary perspective. Here we draw on a unique data set built from extensive interdisciplinary, mixed-method research conducted across twenty-four study sites in Ghana, Malawi and South Africa to offer some reflections regarding observed broader trajectories of change, while still acknowledging the crucial importance of local context.

While diverse economic and political histories have helped shape migration practices in each of the three study countries, circular migration is a remarkably persistent element across all, albeit tempered by expanded city-ward and international migration flows. In Ghana, northerners continue to travel seasonally to the better-resourced south for work, although opportunities in urban centres and the global North are increasingly sought from all regions; Malawi's poverty has long encouraged strong, often circular, migration to its cities and to neighbouring South Africa; South Africa's black labour is no longer corralled into 'homelands' and male contract-labour spaces, but in the context of high unemployment, shorter- or longer-term circular migrations between rural and urban sites persist (Stichter 1985; Potts 2010: 68-70). Given this continued prevalence of circular migration, it is hardly surprising that communications across stretched families figure so strongly in current stories of daily life. However, the material nature of communications has drastically altered over the last two decades: the proliferation of mobile phones, together with the new communicative environment this presents, is what lies at the core of the discussion that follows.

The mobile phone is a remarkably significant, mostly twenty-first-century arrival on the communications scene in sub-Saharan Africa. Prior to Africa's first mobile call, in 1987, there were only landlines, largely the preserve of elites (Vodafone 2005); by 2005, mobiles accounted for at least three-quarters of all telephones in nineteen African countries, and in the last decade the expansion of access to phones - far higher than actual ownership, since sharing is widespread - has been dramatic across most of the continent (Castells et al. 2007; Etzo and Collender 2010; Porter et al. 2012). The observation of a young woman teacher in rural Malawi that 'When one has a phone, it's a symbol that things are working in life' reflects a view that is increasingly widespread across a wide age range. However, it is young people - male and female - who are in the vanguard when it comes to the mobile phone's strategic and creative application: whether as artefact or actor, they perceive its incredible power and quickly apply 
themselves to becoming experts. ${ }^{3}$ From Ghana, where one farmer respondent referred to the mobile phone as his 'second wife', because of the money it costs him, to Sudan, where Lamouraux (2011: 140-1) reflects on the sliding phone known as 'Satan', and beyond, the device and its increasingly remarkable applications have inveigled themselves into a key position in everyday life, even among the poorest. Practices involving social networking, mobile money, transport ticketing, utility bill payments and so on - who knows what next? - ricochet from place to place and back again.

In the global North, a substantial geographical literature has charted the compression of time and space produced by developments in transport and ICT, recognizing how the social, physical and technological realms are increasingly mutually constitutive of one another (Schwanen and Kwan 2008). In Africa, however, the impact of rapidly evolving physical and virtual mobility practices ${ }^{4}$ is arguably even more dramatic, as temporal and spatial mobilities become intertwined as never before, entangling families and their constituent members in an increasingly complex net of communications (Porter 2015). Young and older people's stories from either end of stretched families offer an entrée into a world where the connectivities now presented by the mobile phone bring a different kind of closeness and knowing, new images and understandings of home and away, new hopes and opportunities - but not the elimination of persistent fears (Nyamnjoh 2013a; 2013b). Meanwhile, the growing potential to defy distance and time, by making increasingly low-cost connections to home feasible from distant places, even far beyond the African continent, is inevitably reflected in both changing migration trajectories and associated mobility practices (de Bruijn et al. 2013).

Emotion, arguably a slippery word (Beatty 2013; 2014), is entangled in complex ways with these stories about ICT-enabled connections over space, as a growing body of (principally anthropological) literature attests. Examples on Africa include Nyamnjoh (2005; 2013b) on Cameroon's diaspora and Kane (2012) on Haalpulaar migrants in Senegal. Elsewhere, examples include Wallis (2013) on young migrant women in Chinese cities ${ }^{5}$ and Madianou and Miller (2012) on Filipino mother-child transnational relations. Migrants have to grapple not only with building new lives but also with homesickness and hostile host communities; home-dwellers, meanwhile, may sorely miss and even resent the absence of a family member. This suggests the centrality of emotional dynamics, as separated

\footnotetext{
${ }^{3}$ This is also observed by Archambault (2012), for instance, in urban Mozambique. Older people, by contrast, tend to be much less confident and active in their phone use and often depend on younger family to call people and to save numbers for them. This is exemplified by the evident frustration of the twenty-one-year-old man in rural coastal Ghana who observed: 'My mother has one but she scarcely uses it. Hers is always off ... She does not know how to use it very well.'

${ }^{4}$ Physical mobility here encompasses travel by foot or other means of transport; virtual mobility refers to the leapfrogging of physical space (for instance, without leaving home), now increasingly achieved through information and communication technologies (ICT).

${ }^{5}$ Wallis (2013: 89), for instance, observes the emotional labour that migrant women in Beijing expend in buying and using mobile phones, which embody 'deep emotions and yearnings for a modernity that is always produced as partial ... a hybrid rural-urban subjectivity'. Owning a phone is a way of asserting autonomy from an 'othered' rural identity: a form of empowerment associated with discourses of self-improvement.
} 
individuals look to manage their family connections: 'the tension between physical proximity and distance is an important lived reality' (Svašek 2010: 868). Such intricately intertwined positive and negative emotions, shaped by memory, imagination and expectations, are thickly threaded through the data we present in this article. The interplay of emotions, in some cases further mediated by significant generational issues, helps shape and characterize phone-enabled communication at both ends of stretched families. This is reflected in narratives concerning not only the content of communication but sometimes also its practice, both regarding the choice of communication mode (voice or text) and in decisions about if and when to meet face to face.

The article commences with a review of methodology and sets the scene regarding the role that migrants commonly play in promoting ICT connectivity with home-based family, including the responsibilities they often assign to young people (male and female). Evidence follows regarding the significance of the mobile phone as an emotional prop, from both home and migrant perspectives. This is then balanced by an examination of how emotional ties may become complicated by phone-facilitated requests or demands for resources. The final section examines a potential marker of changing space-time configurations associated with expanded virtual communication: migrant practices of visiting home and the potential emotional impacts of reduced co-presence. Final reflections emphasize the potential for further complexities and uncertainties to emerge as the spatial boundaries between places become ever more blurred.

\section{'When the far away becomes nearby'6}

Since 2006, we have been researching mobilities in twenty-four sites across Ghana, Malawi and South Africa: four site types (poor urban high density, peri-urban, rural with services, and remote rural) in each of two agro-ecological zones per country. $^{7}$ Our first study (2006-10) of young people's physical mobility and access to services focused on those aged from nine to eighteen years; however, during this research, the virtual mobility afforded by the mobile phone emerged as a significant component of daily mobility practices. ${ }^{8}$ The second study (2012-15) concentrated specifically on how mobile phones are influencing young people's lives and incorporates a wider age range (nine to twenty-five years). ${ }^{9}$

Our method has been somewhat unusual from the start, in that we commenced by training seventy young people (schoolchildren aged eleven to nineteen years) in 2006 as co-researchers. They helped establish key questions for further substantial qualitative and quantitative research by the academic research teams (Porter et al. 2010; Porter 2016a). Some of those 'young researchers' have continued to work

\footnotetext{
${ }^{6} \mathrm{McHugh}$ (2000: 85) refers to Georgia O'Keeffe's use of this phrase in correspondence. This is also referenced by Nyamnjoh in de Bruijn et al. (2013: 162).

${ }^{7}$ Both studies were funded by ESRC-DFID and led by the first author. Staff from the University of Cape Town participated in the second project only.

${ }^{8} \mathrm{See}<\mathrm{https}: / /$ www.dur.ac.uk/child.mobility/>.

${ }^{9}$ See $<$ https://www.dur.ac.uk/child.phones/>.
} 
with us in the phones project, joining the academic teams and contributing to both qualitative and survey components. In the first (mobility) project, our research teams undertook around 1,400 qualitative interviews and surveyed 3,000 young people. In the second (phones) project, the qualitative component (over 1,600 interviews) included both thematic story-based interviews and 'call-register' interviews covering phone/sim card contact lists, recent calls/texts/missed calls and interactions/chat on social network sites, plus a survey of 4,500 young people (3,000 aged from nine to eighteen years, and 1,500 aged from nineteen to twenty-five). Both projects involved some in-depth interviews with older people as key informants, including parents, phone-related business operators and teachers. In total, we have two very substantial data sets with the potential for extensive triangulation both across years and between different types of information. These triangulated data sets facilitate distinctive insights into ICT usage within Africa. Hitherto, as noted earlier, most analyses have been restricted to individual sites or countries and to either ethnographic or quantitative methods, depending on disciplinary perspective. Our studies utilize mixed methods within an explicitly interdisciplinary approach.

While our research has not focused on migration per se, many of our interviews have been with members of stretched families who have often drawn specific attention to the role that mobile phones now play in the practices of family interaction. Within each of our study countries we have encountered migrant and home-based members of stretched families in diverse contexts; these have varied according to research site, but all our respondents live in relatively poor neighbourhoods. The groups within our study can be categorized as follows:

- Rural-based respondents linking to urban migrant family members and urbanbased migrant respondents linking to rural home family. These are notably young people in towns and cities for secondary school, employment or job searches, while young siblings and older adults may remain at home in the village.

- Urban-based migrant respondents linking to home family in another urban location. This group is often associated with young people moving up the urban hierarchy as they search for better opportunities.

- Rural-based migrant respondents in one rural location linking to home family in another rural location. These are usually family segments moving to new farming or farm labour opportunities, on a seasonal or longer-term basis, a pattern particularly common in our Ghana forest zone sites. ${ }^{10}$

Some are also members of transnational families:

- respondents in our Ghana sites connecting with family elsewhere in West Africa, Libya and across the world;

- respondents in Malawi who interact with migrant family members in South Africa (principally men who have moved to work in the mines or domestic jobs) or Mozambique; and

\footnotetext{
${ }^{10}$ In Ghana, inter-regional migration dominates, but with shorter distances among the poorest people, thus migration from the poor northern areas is mostly to relatively closer areas of the forest zone rather than further south (see Castaldo et al. 2012).
} 
- respondents in South Africa (principally our Gauteng and North West Province sites) who are transnational migrants and link back to family in Malawi, Zimbabwe, Mozambique, and so on. ${ }^{11}$

The qualitative data offer a richly textured account of individuals' interaction practices with their non-resident kin and associated emotional experiences, while our phone survey data enable us to build a wider picture regarding the patterns of communication with kin, as opposed to non-kin, phone requests to kin for resources, both financial and material, and the perceived impact of phone use on patterns of physical travel. Triangulation across the data sets allows us to draw together broad conclusions regarding the intersection of actual and virtual mobility modes across stretched families in the new dispensation.

\section{Migrants as promoters of connectivity}

Many home-based family members are restricted in their opportunities for connecting with migrant family because of their limited access to resources, although they may 'buzz' or 'flash' (i.e. calling then immediately ending the call, so no cost is incurred) or send a 'call me' to their perceived more affluent migrant kin, to remind them of their existence and to suggest that contact would be welcome. As an eleven-year-old girl in our remote rural study settlement in Gauteng/ North West Province of South Africa explained: 'Sometimes I would send [my married sister in town] a call-me message and she would respond as soon as she gets airtime.' Migrants of both genders, meanwhile, often take the lead in communication across the stretched family, and not only because they have, or are perceived to have, more resources and are expected to take the initiative. Our interviews suggest that a mix of emotional needs, sentiment and insurance drive their actions. ${ }^{12}$

In the first place, it is often migrant family members (especially city residents) who buy a phone for their rural-based kin so that they can keep in touch with home. However, because older people tend to be much less confident and active in their phone use than younger people, and often depend on younger family members to make calls and save numbers for them, it is often youth, male or female, who are given the handset. This was the case, for instance, with a sixteen-year-old in remote rural Malawi who was gifted a phone by her migrant sister because she is 'the only person who is well conversant with cell phone use in my family'. Arguably, as we have discussed elsewhere in the context of intergenerational relations, this places many young people - male and female - in

\footnotetext{
${ }^{11}$ Information in a UN High Commission for Refugees report in 2012 implies that South Africa was the largest recipient of individual asylum applications worldwide from 2005 to 2011: 'Whereas South Africa had been the leading destination country of new asylum-seekers for the six previous years, asylum levels there dropped by almost half in 2012, compared to 2011' (UNHCR 2013: 26). However, this claim is open to dispute (see Greyling 2016).

${ }^{12}$ Even though our survey data show that young people aged between fifteen and twenty-five years who are resident in urban areas have a far lower proportion of their phone communication with relatives than do those resident in rural areas, the importance of family resonates through the qualitative interviews (see Porter et al. 2015).
} 
positions of some power as they take on what is potentially a significant role as 'info-mediary' in their families (see Porter et al. 2015).

Migrants often initiate and encourage regular family calls on a weekly or monthly basis, as exemplified in the following cases:

I have a cousin, who is in South Africa, whom I talk with often because I cannot travel there, it is too far ... I speak with him almost every week. Honestly, he is the one who calls me ... it has been maybe four years since he left Malawi. He works as a house boy. ${ }^{13}$

My husband is in Italy ... Depending on his availability he calls between twice and thrice a week. ${ }^{14}$

In some cases, migrants demonstrate their desire to maintain a stake in the home environment by investing in small projects, much as they did before the advent of mobile phones. Contributions to farming enterprises and small construction projects still seem very common. Building a house, in particular, is a key signifier to home kin that the migrant will ultimately return, even if only in old age, or after death. ${ }^{15}$ It may also perhaps symbolize to the migrants themselves the comfort of a place waiting in the ancestral home, should they need or wish it, however far they have travelled and however long since they have been physically present there. ${ }^{16}$ The fact that such activities often now justify regular phone communication with family members may also be part of the attraction for migrants: communication through a lengthy period of construction, and perhaps subsequently for maintenance, not only helps with controlling the project as it proceeds but can also help build a shared understanding of the project and a cementing of the bonds that tie migrant and home. The following example demonstrates how phone interaction through such a building project has strengthened transnational family connections and has helped build a level of trust that is valued by the homebased kinsman but may ultimately also benefit the migrant and his progeny:

[My brother in Canada] is building a house in Kumasi and I am in charge of that project. He has been sending me money through Western Union. When he does so, he calls me on [the] phone to give me the PIN code which I use to go to the bank to collect the money ... Three months ago, [my brother] called me and gave me a PIN. I went to the bank the next day and withdrew some money. It was meant for his building project. Part of it was also given to his two children, who are attending school in Ghana. For the building project, I bought some materials ... I also called the person working on the building. The following week, I called [my brother] and gave him a rundown of the expenditure incurred on the building. We went through every bit of the expenses one after the other on [the] phone. He was satisfied with the way I used the money. The phone helps me to maintain trust and confidence with my brother. Without it, I would not be able to explain the details of the

\footnotetext{
${ }^{13}$ Twenty-four-year-old male trader, remote rural Malawi.

${ }^{14}$ Thirty-three-year-old woman trader, urban Ghana.

${ }^{15}$ See Potts (2010: 191-4) with regard to the house as an expression of a migrant worker's membership of the home community in Zimbabwe, shaped by both economic and socio-cultural factors, and for a further discussion of the power of cultural versus economic affiliations to home, drawing on a range of anthropological, historical and geographical literature for Africa, all emphasizing the crucial importance of local context.

${ }^{16}$ For instance, see Fortes (1949) on the Tallensi.
} 
expenditure involved in his building project and other issues ... the phone helps us to reconcile all expenses ... with the phone, I am aware that he can check on me anytime. This has made me to be careful with him by making sure that anything he asks me to do, I do with due diligence. The other thing is the frequency with which we contact each other. Those days, it was very difficult for relatives abroad to contact those at home. Some people could not tell the whereabouts of their relations abroad. But today, there are regular contacts between us in Ghana and those abroad. ${ }^{17}$

Even when migrants are well established elsewhere, as in the case above, keeping connected to home is often perceived as an essential insurance strategy, both for themselves and for their dependants. It is seen as a potential safety net of considerable importance, but especially in contexts where lives and livelihoods may be precarious. This is exemplified in the following observations from a middle-aged pastor living in a poor urban neighbourhood in Malawi:

I use my phone to make my children connect to their grandparents and relatives. What I do is that I call one of my relatives and tell him or her that my children want to speak to them. Therefore, as my kids talk to their relatives through the phone they feel connected to friends and relatives [so] that, even if I die today, they can know where to go because they know where their relatives are through the phone.

Some who have migrated may also occasionally phone to encourage (mostly younger, often male) family members to migrate and join them, as reported in the following interviews:

I also have the contact numbers of my uncles in Libya. They usually call me to encourage me to learn hard so that when I complete senior high school, they can help me join them. They have not been there for long so they do not have a lot of money. Last Christmas they sent us some money to be shared among my siblings. Due to the nature of their jobs, they do not get a lot of time to communicate with us frequently. ${ }^{18}$

I received a call from my uncle who is [in] Gauteng mines yesterday. He wants me to come there so that I can find jobs in [the] mine. ${ }^{19}$

Stories over the phone about the good life to be had in the city can present an emotional inducement difficult to ignore. The married young farmer in rural Malawi who connects regularly with his brother-in-law working in Johannesburg is clearly tempted: 'He told me about how people in Jo'burg live and that it is very easy to make money ... I long for him to call.'

\section{Emotions across space: a different kind of closeness?}

Because of mobile phones, the members of many stretched families now communicate remarkably regularly, even daily - including, for some, transnationally. Our survey data on youth phone use present an interestingly gendered pattern to phone

\footnotetext{
${ }^{17}$ From an interview with Stephen, a forty-nine-year-old man farming in Ghana's forest zone.

${ }^{18}$ Seventeen-year-old boy, urban Ghana.

${ }^{19}$ Twenty-four-year-old man, remote rural area in Eastern Cape, South Africa.
} 
communication, with young women aged sixteen to twenty-five more likely than their male counterparts to make contact with family networks in all three countries, despite overall lower levels of female phone ownership in both Ghana and Malawi. $^{20}$ This mirrors gender patterns found elsewhere, for example in Jamaica (Horst and Miller 2006: 91). However, our qualitative data offer many instances, among both genders, where the phone is a virtual umbilical cord, ${ }^{21}$ as young migrants express their need to communicate with mothers at home.

I can talk to my mother to check her mood and well-being and she can do [the] same. ${ }^{22}$

I call my mom [in the village] once in a month. This is my own plan. I [will make] a call in two weeks' time because I have missed my mom so deeply. ${ }^{23}$

I spoke to my [city-based] mother yesterday in the evening. We spoke for forty-five minutes; she wanted to say hi and good night. ${ }^{24}$

I am doing nursing second year in East London ... I use [my] cell phone to hook up with my relatives. I love my mom so I call her often and ask how is she..$^{25}$

Other migrants talked about close connections to fathers, to special uncles and aunts, and to grandparents. David, ${ }^{26}$ a young man in rural Malawi whose father had left for South Africa a decade previously, is now in close touch with him by phone:

We get the messages very fast and very frequently (once a week). I feel very happy to talk to him. I can easily tell him my problems and he can also provide me with the basic needs. Now that he calls frequently, I can talk [about] issues affecting our family and he usually supports us. Sometimes he gives the money to someone coming to Malawi ... sometimes he uses [the] post office.

A sixteen-year-old orphaned schoolboy in urban Malawi similarly spoke about contact with his uncles in the rural north. He has visited them only once but contemplates joining them in the future; in the meantime, 'through phoning them, I share their life'. Susan, a fourteen-year-old in the same location who misses her village-based grandmother, has talked to her occasionally on the phone: 'It was so exciting. I love my grandmother but she stays too far from me. When I managed to talk to her, I was delighted and felt like she was here with me. The phone united us.' (A few years earlier, an emergency had been averted following a phone call from the grandmother when she faced starvation.) Tisunge, a

\footnotetext{
${ }^{20}$ This was only statistically significant for Ghana; for more detail, see Porter et al. (2015).

${ }^{21}$ As referenced by Pelckmans (2009: 28).

${ }^{22}$ Nineteen-year-old secondary school boy, living with his brother in urban Ghana.

${ }^{23}$ Seventeen-year-old boy, living with guardians in urban Malawi. They promised to send him to school but had not done so.

${ }^{24}$ Eleven-year-old girl, living with her grandmother in our remote rural study site, North West Province, South Africa.

${ }^{25}$ Twenty-one-year-old girl, the second youngest of twelve, interviewed on a home visit to the remote rural study site, Eastern Cape, South Africa.

${ }^{26}$ Pseudonyms are used throughout the article.
} 
young woman living in the nearest city, having sold her phone to pay for transport for a visit home, uses her partner's handset to call her favourite uncle regularly 'to know how he is doing in life and to chat with him stories of our home village'. Time and time again in such accounts, the emotional importance of hearing the voice as opposed to text messaging is emphasized, mirroring the preferences of expatriate Filipino mothers communicating with distant children (Madianou and Miller 2012: 108). Voice calls can encompass emotional matters through synchronicity and lessen potential ambiguities, misunderstandings and conflict. In Tisunge's case, however, memories and imagination also come strongly into play (Svašek 2010: 868).

While such connections can give much pleasure, an absence of contact can also generate unease, as in the following case:

I last called my sister [a street trader in Durban] yesterday. I was just checking how is she doing since it has been long. And she does not call; I do not know why. I did not send a text because I prefer calling... And you can hear the voice of the person when you call. And you can tell by hearing a voice if a person is not sick.

Here, the potential health status of a sibling, which seems to be creating considerable anxiety for our fifteen-year-old respondent in peri-urban Eastern Cape, South Africa, can be ascertained only by voice. Similar sentiments may be behind the voice calling noted in the following narrative, which is also centred around health concerns:

Monday, I sent a text to my [senior] brother in Senegal to send money to take care of my mother because she's not feeling well [and] he called back to tell me that he will send the money. I didn't use my credit to call him because the charges are that high when you call outside from Ghana. But anyway, he called for us to talk about so many things ... He's always been calling to ask how she's been faring. He talks to her too, but the only thing is that my mum has asked us not to be telling him about her sickness ... he's so worried about [her] condition. Sometimes he's unable to concentrate on the work he's doing ... and wishes he could come to see her but he has no chance at the moment. ${ }^{27}$

Kofi says he initially texted to request money because a call would have been too expensive, but perhaps texting also enabled him to avoid the embarrassment of a direct request for funds (Madianou and Miller 2012: 132). For the most part, however, voice is widely preferred to text when migrants contact close homebased family, as noted above. It offers certainty that the message has reached the recipient, it is essential when high levels of illiteracy prevail, as is often the case among older family members in village homes, and - above all - it brings the comfort of hearing familiar voices. Even when the discussion is trivial, with seemingly little purpose, such so-called 'phatic communication' may serve a crucial social function, confirming the persistence of underlying bonds (ibid.: 88).

\footnotetext{
${ }^{27}$ Kofi, a nineteen-year-old taxi driver in peri-urban Ghana.
} 


\section{Mobilizing resources}

Requests for resources figure substantially in the phone conversations of the young people we interviewed in stretched families: the common pattern, simply expressed, seems to be for migrant members to exchange resources (not only financial but often material) for information about home. The material exchanges we recorded are often very modest and can be seen as reflecting a social landscape in which migrants express sentiments for and loyalty to their home-based kin - an exchange reflecting mutual recognition between giver and receiver. ${ }^{28}$ At the same time, migrants are assumed to be able to help meet the urgent home needs of young people, and the lack of a response to resource requests from home may well be seen as signifying a failure in their social obligations and the precursor to family discord (Melde and Schicklinski 2011: 6; IOM 2012; Tazanu 2012).

The main exception to this pattern of demand is when young people are sent to urban areas for schooling, as then they may well request resources from home. ${ }^{29}$ There are numerous cases of this. For instance, seventeen-year-old James, from a farming family and now in senior high school in urban Ghana, observes:

Because I am schooling I need [a] phone to communicate with my relatives ... Were it not for the phone, I would need to always go [home] to my parents for things I need.

Similarly, Betty in Malawi has:

used the phone to request for uniform ... when I started going to secondary school two years ago. The head teacher had told us that without uniform, I was not going to write my end of term exam. I called my uncle.

Requests from young people at home to migrant family members are commonly directed at aunts, uncles and older siblings. They may be either for money or for specific items:

Last week I made a call [on a borrowed phone] to [my] sister who is working in town [as a nurse]. I called her to ask her [to] help me with money so that I can buy seeds and pesticides for my garden. Since then I have not made any call to her. I only use [my] cell phone when I want to ask for help. ${ }^{30}$

\footnotetext{
${ }^{28}$ Cliggett (2005) suggests that Zambia presents a special case, unlike much of West Africa; for instance, the gifts are small in monetary value, and they link to a core social basis rather than to strong motives relating to rural investment. However, for the young people in poor communities who are at the centre of our study, much of the gifting activity reported in all three countries looks rather similar to the Zambian pattern, being modest in scale and with evident social and symbolic value.

${ }^{29}$ Thirty-seven per cent of Ghanaians, 37 per cent of Malawians and 61 per cent of South Africans who were currently enrolled full time in school had called someone in the previous year to ask for money specifically for their school or college expenses. The vast majority of those requests were made to a relation: in Ghana and Malawi this was most commonly a relative other than the parents (with requests to fathers in second place), while in South Africa requests were predominantly addressed to the mother (see Porter et al. 2015).

${ }^{30}$ Eighteen-year-old boy, remote rural Malawi. He has written her number on a piece of paper which he keeps safely at home, because of fears of losing it.
} 
I last called [my aunt in East London] two days ago ... I asked for money. She said I must wait until the month end. She uses e-wallet to send [it]. ${ }^{31}$

I often call my mother to ask for money, airtime and clothes. She buys me airtime and brings clothes when she comes back home. She normally visits us twice or three times a year. ${ }^{32}$

In some cases, regular recourse is also now being made to family members living outside Africa, who are perceived as particularly likely sources of assistance. Expectations here are clearly more substantial. The following example provides a picture of the degree to which dependence on overseas remittances can develop (World Bank 2011). ${ }^{33}$ The respondent is a farmer in his late twenties living in coastal Ghana whose elder sister has been resident in the UK for many years. She was taken there initially by an Accra woman to work as a housekeeper for her, but when they fell out, she joined another Ghanaian woman with a hairdressing business, somewhere in the UK - the farmer says he does not know where:

We are just farmers and we can hardly make ends meet. So we often call [my sister] to send us some money ... Whenever she gets some money for us, she first calls me and informs me of her intention to send us some money. We usually agree that she calls to alert me after sending the money. We also discuss on [the] phone what to use the money for and allocate the money for different purposes: some for our mother, our children, our aunties and other people. Later, when she does the transfer, she calls me and [gives] me a PIN. Initially I was not good at reading and I cannot write numbers very well. So [she] often called my other sister ... to write down the number. [She] then calls me to arrange for us to go to Ghana Commercial Bank ... to collect the money through Western Union money transfer.

Over time, this family's dependence on remittances has deepened:

Now, with the phone, the distance between here and [the] UK has reduced drastically ... Whenever I am hard pressed, I just buy some credit and call my sister and ask for some money. At worst, in less than a month I am able to get some money from her. Indeed, when I hear some people say [the] phone has no use or is not important, I laugh, because I feel such people have not experienced phone use like I have. Keeping in touch with your family all [the] time, no matter your location, is the most important thing the mobile phone has brought to mankind.

Whether addressed to family in the home country or overseas, many of these requests seem to be regular, almost routine, promoting the perception of migrant relations, especially those in the diaspora, as 'disposable wallets on

\footnotetext{
${ }^{31}$ Eighteen-year-old girl, urban South Africa.

${ }^{32}$ Fourteen-year-old girl, living with her grandparents in remote rural Eastern Cape. Her mother bought her the phone and now buys airtime because she worries if she receives 'callbacks' that something bad has happened to her daughter.

${ }^{33}$ Castaldo et al. (2012) note that, while the World Bank (2011) estimated the total inflow of international workers' remittances received by Ghana in 2006 at US $\$ 105$ million, and the individual sums of money sent by international remitters are usually larger (sometimes much larger), the total of internal remittances is higher than international remittances.
} 
legs' (see Nyamnjoh 2005: 244 on Cameroon; see also Nyamnjoh 2013a on Senegalese migrants). The scale of remittance flows is well illustrated by reference to our survey data. Among the nine- to twenty-five-year-olds surveyed in 2013-14 who had used a phone for communication purposes in the twelve months prior to the survey $(\mathrm{N}=3,506), 41$ per cent in Ghana, 45 per cent in Malawi and 51 per cent in South Africa had requested money (either a loan or a gift); over 80 per cent of the requests in all three countries were to family members. Mobile money services now aid many such transfers and are used frequently by urban residents to remit to family in rural areas. ${ }^{34}$ For requests for material goods, the respective figures were 36 per cent in Ghana, 39 per cent in Malawi and 65 per cent in South Africa; 95 per cent of requests in this case were to family members. In all three countries there was no significant gender difference regarding requests for either money or material goods.

Inevitably, some migrants find the burden of these requests excessive. As one middle-aged Ghanaian migrant farmer observed, with some chagrin:

Before the advent of [the] phone, I used not to get information regularly from my people at home [in northern Ghana] so I was quite free from family problems ... I can only get such information [if] they send someone who knows where I was to come and deliver the message to me. So, I was indeed free from family problems. But today, with the mobile phone, almost all family members have been calling on me to solve their financial problems. This actually puts financial pressure on me.

And when resources fail to appear, the disappointment can be devastating:

Sometimes it becomes difficult to reach [my father in South Africa] because of [the] network and also sometimes my father failed to send the money due to lack of transport so it pains me very much and also I become very angry. ${ }^{35}$

I don't currently have any international contacts on my phone even though I have lots of relatives outside this country. They disappoint too much. Sometimes they call and give huge promises and they end up disappointing you. That's why I do not trust them. After such episodes I only delete their numbers. ${ }^{36}$

With the increasing availability of mobile money services across Africa, pressure on migrants is likely to increase further, since those home families with high expectations of their ability to help financially may now anticipate almost instant transfers of funds, and demonstrate little gratitude for gifts received.

\footnotetext{
${ }^{34}$ This was demonstrated by Morawczynski (2009) in an early example of M-Pesa in Kenya, where there were particularly substantial potential benefits reported for rural women. She also stresses how the act of sending money home had not merely practical value but also symbolic function: 'With each transfer, the migrant was sending an important message - that they had not forgotten their obligation to the village whilst residing in the city' (ibid.).

${ }^{35}$ Fourteen-year-old girl, remote rural Malawi. She had been calling her father to ask for a torch and funds to support her self-boarding expenses during the school examinations period, when she needed to stay close to the school rather than walking four or more hours between home and school each day.

${ }^{36}$ Twenty-year-old male shop worker, urban Ghana.
} 


\section{The home visit: a marker of changing space-time configurations}

Physical and virtual mobility practices of stretched families in Africa have long been complex and contingent, shaped on the one hand by the mesh of expectations and obligations in which relations - especially intergenerational ones - are commonly entwined (Nyamnjoh 2005), and, on the other, by such considerations as travel costs (including money, time, distance and likely travel hazards), which may downgrade the value assigned to co-presence. In today's world, available resources, urgency, emotion, opportunity and uncertainty may all be implicated in the delicate decision as to whether and when a face-to-face visit is essential or a phone call or SMS to home might suffice.

For stretched families, the visit home by migrant members is often a significant event that merits celebration, albeit perhaps tempered by anxiety. For the migrant contemplating a visit home, meanwhile, the costs of the visit must be weighed carefully against the potential pleasure of meeting once more with family and friends in the home environment, often 'simultaneously loved and vexed', 'where you were hatched' (McHugh 2000: 76). ${ }^{37}$ The costs are by no means insubstantial first there are the potential tribulations, dangers and financial costs of getting home. These include road accidents in a continent with the highest traffic accident rates in the world, expensive transport fares, the potential for robbery when travelling home with gifts, and extortion by police and other authorities on the road. Secondly, there is the need to demonstrate the success of migrant life - to arrive wearing smart clothes and bearing anticipated gifts. The transformative power ascribed to migration in rural Mali, for instance, is such that young male Dogon returning home from work in Ghana's cities are perceived to be 'reborn ... Their marvellous clothes on their clean bodies lend them the image of men who have reached the summit of perfection' (Dougnon, 2012: 163; see also Thorsen 2006: 103-6 on Burkina Faso). The total requirements for the visit can thus be substantial, as reported in the following Zambian context:

For a typical young urban migrant from the Gwembe Valley, settled in town for a year or so, embarking on a trip to the village costs at least a third of his monthly salary in transport alone. If he gives a chitenge to his mother, and trousers to his mother's brother, this is at least another quarter of his salary. These costs combined with lost pay on missing work days, and other expenses that inevitably arise, result in an extremely expensive endeavour. (Cliggett 2005: 43)

Before phones, the timing of the home visit was a complex decision, involving the would-be visitor weighing available resources against second-hand news. Letters, photographs or messages sent with travellers were presented by our respondents as the main alternatives, or sometimes cassettes. These took time and were by no means always successfully executed - letters had a tendency to disappear and depended on access to people at both ends of the communication who were literate; and messengers might take some weeks - or even months - before they met with the recipient, as a few respondents recounted. Thus, the occasional, irregular visit home was essential, if at all feasible, especially when the need to discuss

\footnotetext{
${ }^{37} \mathrm{McHugh}$ 's reference is to an African-American migration context, citing Stack (1996: 71).
} 
sensitive private affairs arose. The mobile phone has now revolutionized modes of communication across the stretched family:

We used to write a lot of letters to our relatives outside the country or record our voices on cassette and send to them and they too reply in the same way. But now because of [the] phone, all these troubles are no more. Even for people who could not read and write, their letters should be written for them by strangers who hear everything ... there was no secrecy or privacy on conversation with others. But now there is a direct [communication] between me and my daughter [living in Italy] without any third party. My daughter calls every week, especially in the evening; sometimes she calls more than twice a week depending on her availability. ${ }^{38}$

However, the phone has also introduced new complexities when it comes to visiting home, precisely because it brings the faraway near, enabling such a strong virtual presence that actual physical visits are arguably far less essential than in the days when communication depended mainly on letters or messengers, especially when funds are short. As one fifteen-year-old Ghanaian schoolboy succinctly observed: 'I often use [my sister's mobile] to communicate with my mother. It saves me from travelling ... It saves money, time and risks of accidents.'

Many respondents specifically compared the cost of a journey with that of a phone call:

I get to see my brother less often because I call him instead ... He stays in the city which is very far from here ... I can call him using $50 \mathrm{kwachas}$ airtime while if I am to travel to the city I will spend about 400 kwachas. ${ }^{39}$

If I did not have a phone I would have to borrow money to travel to Kenyase to see my mother ... With [my] phone, I need less than five peswas to do that instead of 3.50 cedis (mini bus) or 2.30 cedis (bus) transport cost. ${ }^{40}$

When migrants are expected to return home with substantial gifts, negative emotions may deepen, encouraging patterns of avoidance.

The trend towards travel substitution is supported by evidence from our survey data in 2013-14. We asked young people (nine to twenty-five years) who had used a phone for communication purposes in the past twelve months $(\mathrm{N}=3,381)$ what impact they thought it had had on their long-distance irregular journeys. In Ghana, 25 per cent said that they were now making fewer such journeys, compared with 65 per cent who said that it had made no difference and 10 per cent who said they were making more journeys. In both Malawi and South Africa, however, where motorized transport is often less regular outside the cities, 40 per cent said that they were now making fewer long-distance journeys, compared with 49 per cent and 42 per cent respectively in Malawi and South Africa who said that phones made no difference and 11 per cent and 17 per cent respectively who suggested that they were making more journeys. Gender differences in terms of

\footnotetext{
${ }^{38}$ Sixty-one-year-old male farmer/grocer, urban Ghana. He cares for his daughter's child, supported by regular remittances from Italy.

${ }^{39}$ Twenty-two-year-old woman, peri-urban Malawi.

${ }^{40}$ Nineteen-year-old schoolboy, urban Ghana.
} 
journey reduction are statistically significant for each country but vary between countries: men report a larger reduction in long journeys than women in Ghana and Malawi whereas in South Africa the position is reversed. However, the reasons for these variations are not clear.

The potential for a phone call to substitute for face-to-face communication can have diverse benefits, costs and consequences, a point well recognized by Urry (2012: 26) in higher-income countries. For some families with migrant members, this reduction in co-presence associated with visits home is becoming an issue, particularly for older people (Porter 2016b). Thus, an elderly male Ghanaian trader lamented how his children used to visit if they heard he was unwell, 'but now phone is making me lonely', because they simply phone instead. While he enjoys the virtual closeness of the phone, it is not enough.

Even some younger people noted negative impacts; this was perhaps most succinctly put by the young man in remote rural Malawi who observed how phones are 'taking away the beauty of people meeting face to face'.

Previously, in the absence of [the] phone, people often visited each other. Face-to-face contacts provided a good avenue for family bonding. But today, one can use the phone to call contacts and family members anytime ... This has affected family ties negatively. Most people working in the cities no longer visit their aged parents and other family. ${ }^{4}$

We spend so much time these days on [the] phone. There are so many things the youth of today don't know because we don't have [the] chance to learn from the elderly - we're always on [the] phone ... I remember I went for [a] funeral in my home town and I didn't even know how to greet in such a public gathering. My brother instantly showed me how to do it ... Had it not been the phone I would be coming ... very often to see my mum and family to be taught some of these things. ${ }^{42}$

Clearly, distance management is a sensitive issue, especially in contexts of widespread poverty. Thus, the tipping point at which co-presence is deemed essential may occur at a later point than in high-income contexts as the friction of distance plays more strongly into individual travel decisions. Often, emergency calls reporting serious illness or worse, or ominous silences, are what trigger a decision to travel home. The transmission of instant news that mobile phones facilitates certainly adds to the stress of decisions about visits: the migrant is no longer 'saved by distance' (Cliggett 2005: 43).

Now as soon as the news breaks, you are told and therefore there is that belief that you can travel in time to meet the burial. Journeys that have to do with informing people about the death of others have reduced because the mobile phone has replaced that service; but now it has increased our journeys to honour such invitations! ${ }^{43}$

The strong expectations of travel home as a response to bad news, and the ensuing disappointment when that visit fails to occur promptly, were particularly strongly evidenced among Muslim migrant farming families in our Ghana forest zone sites,

\footnotetext{
${ }^{41}$ Twenty-two-year-old male farmer, rural coastal Ghana.

${ }^{42}$ Twenty-five-year-old male teacher, rural coastal Ghana.

${ }^{43}$ Seventeen-year-old boy, migrant farmer, rural Ghana.
} 
where burials must take place shortly after death and many retain close links with home in the far north. Ten-year-old Maryam worries about the outcome:

When there is a funeral in the north and they call on us to inform us, but we are unable to attend because there is no money, it causes great conflict. Usually my parents do not discuss what the extended family tells them when that happens.

\section{Conclusion: reconfigurations of migrant-home connectivities}

This article gives some flavour of the diverse and complex ways in which the mobile phone is changing migrant-home connectivities in stretched families. The immediacy of phone communication brings emotional benefits through regular interaction, but also hazards of instant sociality; phone-enabled mobile money transfers allow rapid support in times of crisis, but money demands bring an additional stress to many migrants' lives; calls bring the faraway near, so travel costs can be reduced or avoided, but they may initiate new concerns about reduced co-presence. While we have noted some gender variations in the foregoing discussion, generation seems to be more significant in current reconfigurations. With space and time in their grasp - controlling the spatiality and temporality of news flows (who gets to know what, when and where) - the young 'info-mediary', male or female, can move into a position in which they have greater power in the family than ever before. The potential for a disturbance in the current generational balance of power is particularly intriguing.

Chinua Achebe (1974: 46) likened the world to 'a Mask dancing. If you want to see it well you do not stand in one place.' Studying stretched families has always required more than one vantage point, but now there are ever more complex overlaps: the faraway impedes on the nearby, and vice versa, with potentially complex reverberations; notions of distance and proximity are being redrawn, so that time and space are rearranged in potentially confusing ways; the bricolage of dreams, hopes and (sometimes bitter) experiences that, before the advent of the mobile phone, was largely confined to one place at a time, whether home or away, spills over and becomes entangled with dreams, hopes and experiences elsewhere. Separate spaces are coalescing through virtual connectivity. Migrants have always been required to present a success story at home, but in the past the home visit required that they put this together for only a very limited time; the migrant could then hasten back to their new life. We can hypothesize that the phone, by contrast, is encouraging migrants to pursue persistent multiple identities shaped one way for home consumption, another for migrant life. Our analysis of changing phone networks among urban youth (see Porter et al. 2015) suggests that many are now enhancing their everyday lives by building non-family connections, while still maintaining home family ties, albeit with fewer physical visits home. Since most migrant stories we encountered suggest less bitterness and disillusionment with home interactions than those evident among diaspora Cameroonians (Nyamnjoh 2005), and since the home stories we heard were often threaded with signs of genuine concern for migrant city siblings and children, this strategy makes good sense. It offers a way of embracing modernity in the new life while maintaining the emotional security of family and tradition in the natal home. However, it is important to bear in mind that ICT connectivities 
themselves are changing with amazing rapidity: as the spatial boundaries between places become ever more blurred, collisions have the potential to emerge with disconcerting frequency. Currently, smart phones do not operate in most of our rural sites, but once internet connectivity and Skype reach remote villages, a new phase of home-migrant interaction can be anticipated. The shape that this might take and its likely wider implications for emotional lives at both ends of the stretched household remain to be seen. Outcomes are becoming increasingly difficult to predict.

\section{Acknowledgements}

This research was funded by the UK Economic and Social Research Council and the Department for International Development (ESRC ES/D002745/1; ES/J018082/1). We are most grateful to all our respondents for the time they have given to this study, to the young researchers who have worked with the team since 2006, to the many research assistants, and to our country consultative groups and UK steering group for their advice and support. We also thank the anonymous reviewers for their insightful comments. We wish to acknowledge particularly the contribution of James Milner of the University of Malawi. James, who played a key role in the Malawi research, very sadly died following a car accident in Malawi in September 2014.

\section{References}

Achebe, C. (1974) Arrow of God. 2nd edition. London: Heinemann.

Archambault, J. S. (2012) 'Travelling while sitting down: mobile phones, mobility and the communication landscape in Inhambane, Mozambique', Africa 82 (3): $393-412$.

Batterbury, S. (2001) 'Landscapes of diversity: a local political ecology of livelihood diversification in south-western Niger', Cultural Geographies 8 (4): 437-64.

Beatty, A. (2013) 'Current emotion research in anthropology: reporting the field', Emotion Review 5 (4): 414-22.

Beatty, A. (2014) 'Anthropology and emotion', Journal of the Royal Anthropological Institute 20: 545-63.

Bryceson, D. and U. Vuorela (eds) (2002) The Transnational Family: new European frontiers and global networks. Oxford and New York NY: Berg.

Castaldo, A., P. Deshingkar and A. McKay (2012) Internal Migration, Remittances and Poverty: evidence from Ghana and India. Working paper 7. Brighton: University of Sussex, Migrating Out of Poverty Research Programme Consortium.

Castells, M., M. Fernandez-Ardevol, J. L. Qiu and A. Sey (2007) Mobile Communication and Society: a global perspective. Cambridge MA: MIT Press.

Cliggett, L. (2005) 'Remitting the gift: Zambian mobility and anthropological insights for migration studies', Population, Space and Place 11: 35-48.

de Bruijn, M., I. Brinkman and F. Nyamnjoh (eds) (2013) Side@ways: mobile margins and the dynamics of communication in Africa. Bamenda and Leiden: Langaa and African Studies Centre.

Dougnon, I. (2012) 'Migration of children and youth in Mali: global versus local discourses' in G. Spittler and M. Bourdillon (eds), African Children at Work: working and learning in growing up for life. Berlin: IAS. 
Englund, H. (2002) 'The village in the city, the city in the village: migrants in Lilongwe', Journal of Southern African Studies 28 (1): 137-54.

Etzo, S. and G. Collender (2010) 'Briefing: the mobile phone "revolution" in Africa: rhetoric or reality?', African Affairs 109 (437): 659-68.

Fortes, M. (1949) The Web of Kinship among the Tallensi. London: Oxford University Press.

Greyling, T. (2016) 'The expected well-being of urban refugees and asylumseekers in Johannesburg', South African Journal of Economic and Management Sciences 19 (2): 232-48.

Guyer, J. I. (1981) 'Household and community in African studies', African Studies Review 24 (2-3): 87-137.

Hall, K., A. Ebrahim, A. De Lannoy and M. Makiwane (2015) 'Youth and mobility: linking movement to opportunity' in A. De Lannoy, S. Swartz, L. Lake and C. Smith (eds), South African Child Gauge 2015: youth and the intergenerational transmission of poverty. Cape Town: Children's Institute, University of Cape Town.

Horst, H. A. and D. Miller (2006) The Cell Phone: an anthropology of communication. Oxford: Berg.

IOM (2012) Transnational Families and the Social and Gender Impact of Mobility in ACP Countries: background note. Geneva: International Organization for Migration (IOM).

Kane, A. (2012) 'Haalpulaar migrants' home connections' in P. Hahn and K. Kastner (eds), Urban Lifeworlds in Motion: African perspectives. New Brunswick NJ: Transaction Publishers.

Lamouraux, S. (2011) 'Message in a Mobile': mixed-messages, tales of missing and mobile communities at the University of Khartoum. Bamenda and Leiden: Langaa and African Studies Centre.

Madianou, M. and D. Miller (2012) Migration and New Media: transnational families and polymedia. Abingdon: Routledge.

McHugh, K. (2000) 'Inside, outside, upside down, backward, forward, round and round: a case for ethnographic studies in migration', Progress in Human Geography 24 (1): 71-90.

Melde, S. and J. Schicklinski (2011) Remittances in the African, Caribbean and African Countries. Brussels: ACP Observatory on Migration.

Morawczynski, O. (2009) 'Exploring the usage and impact of "transformational" mobile financial services: the case of M-PESA in Kenya', Journal of Eastern African Studies 3: 509-25.

Murray, C. (1981) Families Divided: the impact of migrant labour in Lesotho. Cambridge: Cambridge University Press.

Nyamnjoh, F. B. (2005) 'Images of Nyongo amongst Bamenda Grassfielders in Whiteman Kontri', Citizenship Studies 9 (3): 241-69.

Nyamnjoh, H. M. (2013a) 'Information and communication technology and its impact on transnational migration: the case of Senegalese boat migrants' in M. de Bruijn, I. Brinkman and F. Nyamnjoh (eds), Side@ways: mobile margins and the dynamics of communication in Africa. Bamenda and Leiden: Langaa and African Studies Centre.

Nyamnjoh, H. M. (2013b) Bridging Mobilities: ICTs appropriation by Cameroonians in South Africa and the Netherlands. Bamenda and Leiden: Langaa and African Studies Centre. 
Pelckmans, L. (2009) 'Phoning anthropologists: the mobile phone's (re)shaping of anthropological research' in M. de Bruijn, F. Nyamnjoh and I. Brinkman (eds), Mobile Phones: the new talking drums of everyday Africa. Leiden and Bamenda: African Studies Centre and Langaa.

Porter, G. (2015) 'Mobile phones, mobility practices and transport organisation in sub-Saharan Africa', Mobility in History 6: 81-8.

Porter, G. (2016a) 'Reflections on co-investigation through peer research with young people and older people in sub-Saharan Africa', Qualitative Research 16 (3): 293-304.

Porter, G. (2016b) 'Mobilities in rural Africa: new connections, new challenges', Annals of the American Association of Geographers 106 (2): 434-41.

Porter, G., K. Hampshire, M. Bourdillon et al. (2010) 'Children as research collaborators: issues and reflections from a mobility study in sub-Saharan Africa', American Journal of Community Psychology 46 (1): 215-27.

Porter, G., K. Hampshire, A. Abane et al. (2012) 'Youth, mobility and mobile phones in Africa: findings from a three-country study', Information Technology for Development 18 (2): 145-16.

Porter, G., K. Hampshire, A. Abane et al. (2015) 'Intergenerational relations and the power of the cell phone: perspectives on young people's phone usage in subSaharan Africa', Geoforum 64: 37-46.

Potts, D. (2010) Circular Migration in Zimbabwe and Contemporary Sub-Saharan Africa. Oxford: James Currey.

Schwanen, T. and M.-P. Kwan (2008) 'The internet, mobile phone and space-time constraints', Geoforum 39: 1362-77.

Skuse, A. and T. Cousins (2005) Managing Distance: the social dynamics of rural telecommunications access and use in the Eastern Cape, South Africa. Working paper 1. London: Information Society Research Group, Department for International Development.

Spiegel, A. D., V. Watson and P. Wilkinson (1996) 'Domestic diversity and fluidity among some African households in Greater Cape Town', Social Dynamics 22 (1): 7-30.

Stack, C. (1996) Call to Home: African Americans reclaim the rural south. New York NY: Basic Books.

Stichter, S. (1985) Migrant Laborers. Cambridge: Cambridge University Press.

Svašek, M. (2010) 'On the move: emotions and human mobility', Journal of Ethnic and Migration Studies 36 (6): 865-80.

Swindell, K. (1980) 'Serawoollies, tillibunkas and strange farmers: the development of migrant groundnut farming along the Gambia River, 1848-95', Journal of African History 21 (1): 93-104.

Tazanu, P. (2012) Being Available and Reachable: new media and Cameroonian transnational sociality. Langaa: RPCIG.

Thorsen, D. (2006) 'Child migrants in transit' in C. Christiansen, M. Utas and H. E. Vigh (eds), Navigating Youth, Generating Adulthood: social becoming in an African context. Uppsala: Nordiska Afrikainstitutet.

UNHCR (2013) 'Displacement: the new 21st century challenge. UNHCR global trends 2012'. Geneva: United Nations High Commissioner for Refugees (UNHCR).

Urry, J. (2012) 'Social networks, mobile lives and social inequalities', Journal of Transport Geography 21: 24-30. 
van der Geest, K. (2010) 'Local perceptions of migration from north-west Ghana', Africa 80 (4): 595-619.

Vodafone (2005) Africa: the impact of mobile phones. Moving the debate forward. Policy Paper Series 2. N.p.: Vodafone.

Wallis, C. (2013) Technomobility in China: young migrant women and mobile phones. New York NY: New York University Press.

World Bank (2011) Migration and Remittances Fact Book 2011. Washington DC: World Bank.

\begin{abstract}
There is a long history of migration among low-income families in sub-Saharan Africa, in which (usually young, often male) members leave home to seek their fortune in what are perceived to be more favourable locations. While the physical and virtual mobility practices of such stretched families are often complex and contingent, maintaining contact with distantly located close kin is frequently of crucial importance for the maintenance of emotional (and possibly material) well-being, both for those who have left home and for those who remain. This article explores the ways in which these connections are being reshaped by increasing access to mobile phones in three sub-Saharan countries - Ghana, Malawi and South Africa - drawing on interdisciplinary, mixed-methods research from twenty-four sites, ranging from poor urban neighbourhoods to remote rural hamlets. Stories collected from both ends of stretched families present a world in which the connectivities now offered by the mobile phone bring a different kind of closeness and knowing, as instant sociality introduces a potential substitute for letters, cassettes and face-to-face visits, while the rapid resource mobilization opportunities identified by those still at home impose increasing pressures on migrant kin.
\end{abstract}

\title{
Résumé
}

En Afrique subsaharienne, les familles à bas revenu ont une longue histoire de migration, avec des membres (généralement jeunes, souvent des hommes) qui s'en vont chercher fortune dans des lieux qu'ils perçoivent comme plus favorables. Les pratiques de mobilité physique et virtuelle de ces familles étirées sont souvent complexes et circonstancielles, mais le maintien du contact avec les parents éloignés est souvent d'une importance cruciale pour préserver le bien-être affectif (voire matériel) de ceux qui partent et de ceux qui restent. Cet article explore la manière dont ces liens sont modifiés par l'accès croissant au téléphone portable dans trois pays subsahariens (Ghana, Malawi et Afrique du Sud) en s'appuyant sur des recherches interdisciplinaires et multi-méthodes portant sur vingt-quatre sites allant de quartiers urbains pauvres à des hameaux ruraux reculés. Les récits recueillis à l'une et l'autre extrémité de ces familles étirées présentent un monde dans lequel les connectivités aujourd'hui rendues possibles par le téléphone portable donnent naissance à un type différent de proximité et de savoir, car la socialité instantanée peut se substituer aux lettres, aux cassettes et aux visites physiques, tandis que les opportunités de mobilisation rapide de ressources identifiées par ceux qui restent renforcent les pressions qui s'exercent sur les parents migrants. 